\title{
Pengembangan Perangkat Pembelajaran Problem Based Learning dengan Metode Mind Mapping dalam Mata Pelajaran IPS untuk Meningkatkan Kemampuan Berpikir Kreatif Siswa Kelas V SD
}

\author{
Fajar Budiyono \\ STKIP PGRI Sumenep \\ fajarbudiyono@stkippgrisumenep.ac.id
}

\begin{abstract}
Abstrak
Penelitian ini bertujuan untuk mendeskripsikan tingkat kevalidan, kepraktisan, dan keefektifan hasil pengembangan perangkat pembelajaran problem based learning dengan metode mind mapping dalam mata pelajaran IPS serta untuk mengetahui hasil kemampuan berpikir kreatif siswa. Penelitian ini merupakan penelitian eksperimen dan pengembangan dengan model 4D dari Thiagarajan, Semmel, dan Semmel. Akan tetapi, dalam tahapan penelitian pengembangan ini telah dilakukan penyederhanaan menjadi tiga tahap, yaitu define, design, dan develop. Penelitian ini dilaksanakan di SDN Pangarangan Sumenep dan SDK Sang Timur Sumenep dengan menggunakan desain uji coba Nonequivalent Control Group Design). Data dikumpulkan melalui lembar validasi perangkat, lembar pengamatan, angket respon siswa, lembar tes tulis yang mengacu pada indikator berpikir kreatif. Data yang diperoleh dianalisis secara deskriptif kuantitatif dan kualitatif. Hasil penelitian menunjukkan (1) hasil produk perangkat pembelajaran yang dikembangkan dalam penelitian ini berupa RPP, LKS dan Tes Kemampuan Berpikir Kreatif dikategorikan valid (2) kepraktisan produk perangkat pembelajaran telah tercapai melalui analisis keterlaksanaan RPP berdasarkan hasil pengamatan yang dilakukan oleh dua pengamat terhadap keterlaksanaan RPP dari pembelajaran dengan perolehan skor rata-rata adalah 3.95 (3) Produk perangkat pembelajaran telah memenuhi kriteria keefektifan ditinjau dari aktivitas dan respon siswa. Frekuensi aktivitas siswa dikatagorikan baik dengan ketercapaian $80.42 \%$ dan $85 \%$ serta hasil analisis respon siswa terhadap pembelajaran menunjukkan $100 \%$ dari kategori respon favorable dan 92\% dari kategori respon unfavorable. (4) berdasarkan hasil uji coba produk diperoleh signifikansi 0.000 lebih kecil daripada alpha 0.05 , maka hipotesis "terdapat perbedaan kemampuan berpikir kreatif'.
\end{abstract}

Kata Kunci: Pengembangan Perangkat, RPP, LKS, dan Instrumen Tes, Problem Based Learning, Mind Mapping, Berpikir Kreatif, Mata Pelajaran IPS 


\section{PENDAHULUAN}

Secara konseptual, pengorganisasian materi mata pelajaran IPS menganut pendekatan terpadu (integrated), artinya materi pelajaran dikembangkan dan disusun tidak mengacu pada disiplin ilmu yang terpisah melainkan mengacu pada aspek kehidupan nyata (factual/real) peserta didik sesuai dengan karakteristik usia, tingkat perkembangan berpikir. Pada jenjang SD/MI mata pelajaran IPS memuat materi geografi, sejarah, sosiologi, dan ekonomi. Dari ketentuan ini, maka secara konseptual, mata pelajaran IPS di SD belum mencakup dan mengakomodasi seluruh disiplin ilmu sosial. Namun ada ketentuan bahwa melalui mata pelajaran IPS, peserta didik diarahkan untuk dapat menjadi warga negara Indonesia yang demokratis, dan bertanggung jawab, serta warga dunia yang cinta damai (Sapriya, 2009).

Terkait tentang proses pembelajaran IPS di sekolah dasar belum sepenuhnya pembelajaran IPS SD terpadu. Kebanyakan pengajar IPS masih banyak mengajarkan IPS sebagai mata pelajaran yang terpisah dimana guru hanya lebih mementingkan teori sosial daripada meningkatkan kemampuan kompetensi siswa dalam dalam kehidupan warga negara. Secara garis besar, kebanyakan guru SD dalam membelajarkan IPS masih sangat nyaman menggunakan metode ceramah dan proses pembelajarannya pun lebih bersifat book oriented. Selain itu, perangkat pembelajaran yang diterapkan bukan hasil inovasi pemikiran guru pengajar sendiri melainkan mengedit yang sudah ada. Tidak hanya itu, rata-rata dari jumlah seluruh siswa yang ada masih terbiasa mencatat penjelasan guru dengan menggunakan kalimat penuh sehingga membuat siswa enggan untuk membacanya kembali.

Dengan begitu, daya kemampuan berpikir kreatif siswa tidak akan tumbuh dan berkembang dalam lingkungan pembelajaran yang hanya duduk manis untuk mendengar dan menerima informasi dari guru. Berdasarkan uraian masalah di atas, maka dapat disimpulkan dalam pembelajaran IPS di SD masih dibutuhkannya upaya inovatif untuk mengembangkan perangkat pembelajaran yang valid, praktis dan efektif sehingga dapat menumbuh kembangkan kemampuan berpikir kreatif siswa. Pembelajaran berbasis masalah (Problem Based Learning) memungkinkan untuk menjawab permasalahan tersebut. Sesuai dengan namanya, pembelajaran berbasis masalah adalah model pembelajaran yang berdasar pada masalah-masalah yang dihadapi siswa terkait dengan KD yang sedang dipelajari siswa. Masalah yang dimaksud bersifat nyata atau sesuatu yang menjadi pertanyaanpertanyaan pelik bagi siswa. PBL berusaha membantu siswa menjadi pebelajar yang mandiri dan otonom. Dengan bimbingan guru yang secara berulang-ulang mendorong dan mengarahkan siswa untuk mengajukan pertanyaan, mencari penyelesaian terhadap masalah nyata dan siswa belajar untuk menyelesaikan tugas-tugas tersebut secara mandiri dalam hidupnya kelak.

Tentu saja, masalah-masalah yang ingin dipecahkan membutuhkan kerangka untuk di analisis dan sintesis. Maka dari itu, alternatif yang sesuai untuk mengoptimalkan kualitas proses dan hasil Pembelajaran berbasis masalah (Problem Based Learning) dalam mata pelajaran IPS adalah dengan bantuan metode mind mapping. Peta pikiran yang dikembangkan oleh Tony Buzan pada tahun 1970-an merupakan metode mencatat yang kreatif, efektif, dan secara harfiah akan "memetakan" pikiran kita (Buzan, 2005). Mind Mapping menggunakan kemampuan otak akan pengenalan visual untuk mendapatkan hasil yang sebesar-besarnya, dengan kombinasi warna, gambar, dan cabang-cabang melengkung. Mind Mapping lebih merangsang secara visual daripada metode pencatatan tradisional yang cenderung linear dan satu warna. Selain itu, mind mapping mempermudah siswa untuk memahami 
penyebab dan konsekuensi hubungan antar masalah. Manfaat dari metode mind mapping sangat cocok dikolaborasikan dengan model PBL dalam mata pelajaran IPS dimana model tersebut titik fokusnya adalah masalah dan upaya pemecahan masalah.

Kolaborasi antara model pembelajaran berbasis masalah (PBL) dengan metode mind mapping dapat menghasilkan dan meningkatkan gagasan-gagasan yang kreatif yang sesuai dengan indikator yang ditetapkan oleh peneliti yaitu; fluency (kelancaran), flexibility (keluwesan), originality (keaslian), dan elaboration (elaborasi). Pengembangan perangkat pembelajaran PBL dengan metode mind mapping ini sangat cocok untuk diterapkan dalam Kurikulum 2013 dengan sub tema "Peranan Manusia". Hal ini dikarenakan kurikulum 2013 mempunyai desain pembelajaran berbasis penemuan dan kontruktivis dimana siswa terlibat langsung dalam penemuan informasi. Berdasarkan uraian diatas, maka penulis termotivasi untuk meneliti tentang "Pengembangan Perangkat Pembelajaran IPS melalui Model Pembelajaran Berbasis Masalah dengan Bantuan Metode Mind Mapping untuk Meningkatkan Kemampuan Berpikir Kreatif Pada Materi Peran Manusia Kelas V SD. Selanjutnya untuk lebih memahami penelitian yang akan dilaksanakan, maka perumusan masalah tersebut dirinci dalam pertanyaan-pertanyaan sebagai berikut:

\section{Bagaimana validitas perangkat pembelajaran} IPS melalui model pembelajaran berbasis masalah dengan bantuan metode mind mapping untuk meningkatkan kemampuan berpikir kreatif pada materi peran manusia yang dikembangkan?

2.Bagaimana kepraktisan perangkat pembelajaran pembelajaran IPS melalui model pembelajaran berbasis masalah dengan bantuan metode mind mapping untuk meningkatkan kemampuan berpikir kreatif pada materi peran manusia yang dikembangkan?

3.Bagaimana keefektifan perangkat pembelajaran IPS melalui model pembelajaran berbasis masalah dengan bantuan metode mind mapping untuk menigkatkan kemampuan berpikir kreatif pada materi peran manusia yang telah dikembangkan?

4.Bagaimanakah hasil kemampuan berpikir siswa antara kelompok eksperimen yang belajar menggunakan model pembelajaran problem based learning dengan bantuan metode mind mapping dengan siswa yang diajar menggunakan model pembelajaran konvensional?

Berdasarkan rumusan masalah di atas, maka secara umum dapat dirumuskan tujuan penelitian ini adalah

1.mendeskripsikan validitas perangkat pembelajaran IPS melalui model pembelajaran berbasis masalah dengan bantuan metode mind mapping untuk meningkatkan kemampuan berpikir kreatif pada materi peran manusia yang telah dikembangkan.

2.mendeskripsikan kepraktisan perangkat pembelajaran melalui model pembelajaran berbasis masalah dengan bantuan metode mind mapping untuk meningkatkan kemampuan berpikir kreatif pada materi peran manusia yang telah dikembangkan.

3.mendeskripsikan keefektifan perangkat pembelajaran IPS melalui model pembelajaran berbasis masalah dengan bantuan metode mind mapping untuk meningkatkan kemampuan berpikir kreatif pada materi manusia sebagai makhluk individu dan sosial yang telah dikembangkan.

4.mengetahui hasil kemampuan berpikir kreatif siswa antara kelompok eksperimen yang belajar menggunakan model pembelajaran problem based learning dengan bantuan metode mind mapping 
dengan siswa yang diajar menggunakan model pembelajaran konvensional.

Pembelajaran pemecahan masalah dipandang penting agar siswa memiliki keterampilan dalam menghadapi dan mengatasi masalah. Berbagai penelitian telah diadakan oleh para ahli mengenai pemecahan masalah sebagai suatu proses kreatif. Menurut Osborn dalam Tilaar (2012) telah mendefinisikan untuk pertama kalinya mengenai pemecahan masalah secara kreatif yang meliputi tiga tingkat: 1) Menemukan fakta yang mengidentifikasikan masalah dan mengumpulkan fakta-fakta, 2) Menemukan ide pemecahan masalah, 3) Menemukan solusi termasuk evaluasi dan implementasi ide. Oleh sebab itu, melalui kegiatan pembelajaran pemecahan masalah ini siswa dihadapkan pada pemecahan masalah yang harus dipecahkan, baik secara individu maupun secara kelompok. Pemecahan yang dilakukan secara individual akan mendorong siswa untuk berpikir kreatif. Apabila dilakukan secara kelompok akan mendorong siswa untuk bekerjaasama sehingga kegiatan pembelajaran berlangsung efektif dan efisien.

Pembelajaran berbasis masalah ini tidak dirancang untuk membantu guru untuk menyampaikan sejumlah informasi kepada siswa. Akan tetapi pembelajaran berdasarkan masalah ini dirancang terutama untuk membantu siswa, (1) mengembangkan keterampilan berpikir, pemecahan masalah intelektual; (2) belajar peran-peran orang dewasa dengan menghayati peran-peran itu melalui situasi-situasi nyata atau yang disimulasikan; dan menjadi mandiri, maupun siswa otonom. Dengan begitu, implementasi dari pembelajaran berbasis masalah adalah untuk mendorong berpikir tingkat tinggi siswa dalam situasi yang berorientasi pada masalah dunia nyata yang kemudian dilakukan pemecahan. Tentu saja, masalahmasalah yang ingin dipecahkan membutuhkan kerangka untuk di analisis dan sintesis. Maka dari itu, alternatif yang sesuai untuk mengoptimalkan kualitas proses dan hasil Pembelajaran berbasis masalah (Problem Based Learning) adalah dengan metode mind mapping. Mind Mapping adalah cara mencatat yang kreatif, efektif, dan secara harfiah akan "memetakan"pikiran-pikiran kita (Buzan, 2005). Lebih dari itu, mind mapping juga merupakan peta rute yang hebat bagi ingatan, memungkinkan peserta didik menyusun fakta dan pikran sedemikian rupa sehingga cara kerja alami otak dilibatkan. Hal ini berarti, mengingat informasi akan lebih muda dan bisa diandalkan daripada menggunakan teknik pencatatan tradisional. Sehingga, pengunaan dari metode mind mapping dapat memunculkan ide-ide baru dan pikiran yang kreatif, mengagumkan, dan menyerap fakta serta informasi baru dengan sangat mudah. Secara konseptual untuk menghasilkan pemikiran yang kreatif dibutuhkan suatu pendekatan memecahkan masalah (Adams, 2006). Proses memecahkan masalah merupakan bagian dari berpikir kreatif. Selain itu, berpikir kreatif bisa distimulasi dengan dengan menggunakan berbagai cara untuk memecahkan masalah (pola pikir divergen,dan juga memberikan output yang bersifat petualangan/penuh mengandung resiko. Biasanya output tersebut berupa menulis kreatif, membuat karya seni, diskusi, mempelajari masalah sosial dan lain sebagainya. Karena alasan tersebut, peneliti memilih pembelajaran problem based learning dengan metode mind mapping dalam mengembangkan perangkat pembelajaran guna menghasilkan dan meningkatkan kemampuan berpikir kreatif.

\section{METODE}

Penelitian ini merupakan penelitian pengembangan (Research \& Development) dan eksperimen dalam bidang pendidikan. Penelitian ini disebut dengan penelitian 
pengembangan karena fokus pada pengembangan pembelajaran IPS dengan model pembelajaran PBL dengan bantuan metode mind mapping yang dikembangkan dalam pelaksanaan pembelajaran untuk meningkatkan kemampuan berpikir kreatif siswa SD kelas V. Produk yang akan dihasilkan dalam penelitian pengembangan ini adalah Perangkat pembelajaran yang terdiri dari Rencana Pelaksanaan Pembelajaran (RPP), LKS dan Instrumen tes berpikir kreatif.

Prosedur pengembangan perangkat pembelajaran dalam penelitian ini menggunakan model 4D dengan modifikasi. Modifikasi yang dilakukan adalah penyederhanaan tahap pengembangan yang hanya terdiri atas tiga tahap, yaitu pendefinisian (define), perencanaan (design), dan pengembangan (develop). Penelitian ini dilaksanakan di Sekolah Dasar Negeri 3 Pangarangan dan SDK Sang Timur Sumenep. Selanjutnya, rancangan desain uji coba perangkat ini menggunakan eksperimen kuasi dengan desain kelompok kontrol yang nonekuivalen (Nonequivalent Control Group Design). Dalam desain penelitian ini terdapat dua kelompok yaitu kelompok ekperimen dan kelompok kontrol. Jumlah dari anggota dari anggota kelompok eksperimen dan kontrol tersebut dibandingkan dengan porsi yang seimbang. Kelompok ekperimen diberikan perlakuan dengan model pembelajaran PBL dengan bantuan metode mind mapping dan perlakuan konvensional pada kelompok kontrol.

Selanjutnya, untuk menentukan kelayakan perangkat pembelajaran yang dikembangkan melalui validasi perangkat, pengamatan, pemberian tes dan pemberian angket. Sementara itu, instrumen yang digunakan dalam penelitian ini adalah lembar validasi perangkat, lembar pengamatan, angket respon siswa, dan lembar tes tulis yang sesuai dengan ketentuan validitas butir soal, realibilitas, tingkat kesukaran tes dan sensivitas butir soal. Sedangkan analisis data yang digunakan dalam penelitian ini yaitu (1) analisis data validitas komponen perangkat pembelajaran dilakukan dengan deskriptif kuantitatif yaitu dengan merata-rata skor tiaptiap komponen, (2) analisis kepraktisan perangkat pembelajaran yang meliputi analisis pengamatan keterlaksanaan RPP dan analisis kendala pelaksanaan pembelajaran (3) analisis keefektifan perangkat pembelajaran meliputi analisis aktivitas siswa dan analisis respon siswa, dan (4) uji prasyarat analisis data meliputi uji normalitas, uji homogenitas dan uji t-test.

\section{HASIL DAN PEMBAHASAN}

\section{Data Hasil Validasi Perangkat Pembelajaran}

\section{Rencana Pelaksanaan Pembelajaran (RPP)}

Rencana Pelaksanaan Pembelajaran (RPP) ditelaah atau divalidasi oleh dua ahli sebelum diimplementasikan dalam pembelajaran. Penelaahan RPP oleh ahli bertujuan untuk mendapatkan koreksi dan masukan dari ahli untuk perbaikan RPP sehingga layak untuk diimplementasikan. Berdasarkan hasil validasi dari dua ahli untuk Rencana Pelaksanaan Pembelajaran (RPP), diperoleh skor rata-rata keseluruhan adalah 3 termasuk kategori cukup baik serta kevalidan dari perangkat tersebut menunjukkan katagori valid dengan penafsiran kevalidan sebesar $80 \%$.

\section{Lembar Kerja Siswa (LKS)}

Lembar Kegiatan Siswa (LKS) digunakan untuk mendukung proses pembelajaran. LKS yang telah dikembangkan peneliti juga harus ditelaah atau divalidasi oleh ahli untuk mendapatkan koreksi dan masukan untuk perbaikan sebelum diimplementasikan dalam pembelajaran. Berdasarkan hasil telaah atau validasi dari dua ahli untuk Lembar Kegiatan Siswa untuk siswa, diperoleh skor rata-rata adalah 3.3 termasuk kategori baik serta kevalidan dari perangkat tersebut menunjukkan 
katagori valid dengan penafsiran kevalidan sebesar $83 \%$.

\section{Tes Hasil Belajar Berpikir Kreatif}

Jenis soal yang dikembangkan adalah soal uraian non objektif tentang masalah sosial sebanyak lima soal yang mewakili indikator peningkatan kemampuan berpikir kreatif yaitu berpikir fluency, flexibility, originality, dan elaboration. Berdasarkan hasil telaah atau validasi dari dua ahli untuk Lembar Telaah Butir Soal diperoleh skor rata-rata adalah 3.65 termasuk kategori baik serta kevalidan dari instrumen tersebut menunjukkan katagori sangat baik dengan penafsiran kevalidan sebesar $91 \%$.

\section{Implementasi Perangkat Pembelajaran pada Uji Coba I}

Penelitian dilaksanakan sebanyak 4 kali pertemuan. Pertemuan pertama dilaksanakan untuk memberikan pretest kepada siswa sebanyak 10 orang guna mendapatkan deskripsi mengenai kemampuan berpikir kreatif siswa mengenai materi yang akan diajarkan dan Pada saat melakukan penelitian uji coba 1, peneliti bertindak sebagai pengajar, dan dibantu oleh pengamat.

\section{Hasil Analisis Keterlaksanaan RPP}

Adapun aspek yang diamati meliputi pendahuluan, kegiatan inti, penutupan dan pengolahan waktu dalam kelas. Sesuai dengan hasil pengamatan yang dilakukan oleh dua pengamat terhadap keterlaksanaan RPP dari pembelajaran problem based learning dengan bantuan metode mind mapping diperoleh skor rata-rata adalah 3.95 termasuk kategori sangat baik serta semua kegiatan yang tercantum dalam langkah-langkah kegiatan pembelajaran telah dilaksanakan dengan ketercapaian 97,5\%.

\section{Hasil Analisis Aktivitas Siswa Selama Pembelajaran}

Setiap aktivitas siswa dicatat, berikut hasil rekapitulasi aktivitas siswa selama proses pembelajaran sebagai berikut:

\begin{tabular}{|c|c|c|c|c|c|c|c|}
\hline \multirow{3}{*}{$\begin{array}{l}\mathrm{N} \\
\mathrm{o}\end{array}$} & \multirow{3}{*}{$\begin{array}{l}\text { Aktivitas siswa } \\
\text { yang diamati }\end{array}$} & \multicolumn{6}{|c|}{ Pertemuan } \\
\hline & & \multicolumn{3}{|c|}{ Pertemuan I } & \multicolumn{3}{|c|}{ Pertemuan II } \\
\hline & & $\begin{array}{l}\text { NP } \\
\text { I }\end{array}$ & $\begin{array}{l}\text { NP } \\
\text { II }\end{array}$ & $\%$ & $\begin{array}{l}\text { NP } \\
\text { I }\end{array}$ & NP II & $\%$ \\
\hline 1 & $\begin{array}{l}\text { Mendengarkan } \\
\text { pejelasan guru }\end{array}$ & 100 & 100 & 100 & 100 & 100 & 100 \\
\hline 2 & $\begin{array}{l}\text { Mengamati } \\
\text { permasalahan } \\
\text { yang disajikan }\end{array}$ & 80 & 95 & 88 & 95 & 90 & 93 \\
\hline 3 & $\begin{array}{l}\text { Merumuskan } \\
\text { hipotesis }\end{array}$ & 75 & 75 & 75 & 80 & 75 & 78 \\
\hline 4 & $\begin{array}{l}\text { Mengumpulkan } \\
\text { informasi dan } \\
\text { menganalisis } \\
\text { masalah }\end{array}$ & 75 & 78 & 77 & 88 & 78 & 83 \\
\hline 5 & $\begin{array}{l}\text { Mempresentasik } \\
\text { an hasil } \\
\text { pemecahan } \\
\text { masalah }\end{array}$ & 70 & 75 & 73 & 88 & 78 & 83 \\
\hline 6 & $\begin{array}{l}\text { Menjawab dan } \\
\text { menanggapi } \\
\text { penyajian } \\
\text { kelompok }\end{array}$ & 75 & 75 & 75 & 78 & 78 & 78 \\
\hline 7 & Menyimpulkan & 75 & 75 & 75 & 78 & 78 & 78 \\
\hline \multicolumn{2}{|c|}{ Rata-rata } & \multicolumn{3}{|c|}{$80.42 \%$} & \multicolumn{3}{|c|}{$85 \%$} \\
\hline
\end{tabular}

\section{Hasil Analisis Respon Siswa Terhadap Pembelajaran}

Angket respon ini diberikan kepada siswa setelah mengikuti kegiatan pembelajaran. Siswa memberikan pendapatnya secara jujur dan tanpa ada unsur paksaan serta tekanan. Adapun hasil rekapitulasi respon siswa terbagi dalam dua pernyataan yaitu favorable unfavorable.

Berdasarkan hasil respon siswa dari jawaban angket yang disebar terhadap 10 orang siswa dalam ujicoba terbatas menunjukkan $100 \%$ dari kategori respon favorable dan $92.5 \%$ dari kategori respon unfavorable. 


\section{Analisis Tes}

Tes diberikan dua kali tes yaitu sebelum dan sesudah pembelajaran. Berikut hasil analisis tes hasil belajar yang mencerminkan kemampuan berpikir kreatif :

\begin{tabular}{|l|l|l|l|}
\hline No & Nama Siswa & $\begin{array}{l}\text { Nilai } \\
\text { Posttest }\end{array}$ & $\begin{array}{l}\text { Nilai } \\
\text { Pretest }\end{array}$ \\
\hline 1 & ANF & 97 & 75 \\
\hline 2 & AF & 91 & 48 \\
\hline 3 & MY & 85 & 77 \\
\hline 4 & ARF & 79 & 66 \\
\hline 5 & RPW & 92 & 51 \\
\hline 6 & NAQ & 96 & 73 \\
\hline 7 & FZ & 100 & 84 \\
\hline 8 & YWD & 99 & 83 \\
\hline 9 & DN & 92 & 87 \\
\hline 10 & KHDF & 85 & 74 \\
\hline
\end{tabular}

Selanjutnya, hasil belajar siswa yang diperoleh kemudian dianalisis untuk menguji instrument tersebut. Umumnya, ukuran yang digunakan adalah validitas, realibilitas, dan sensitivitas butir soal

\section{a. Validitas Soal}

Instrumen pengujian validitas tes dilakukan dengan menggunakan rumus koefisien korelasi product moment. Dalam hal ini perhitungan validitas tidak dilakukan secara manual melainkan dengan bantuan program statistika yaitu SPSS 17.0. Kemudian untuk melihat hasil pengujian valid atau tidak, hasil perhitungan validitas dibandingkan dengan table harga kritik $\mathrm{r}$ product moment. Berikut hasil keputusan validitas item:

\begin{tabular}{|l|l|l|l|}
\hline Item & Rxy & Rtabel & Keterangan \\
\hline 1 & 0.689 & 0.632 & Valid \\
\hline 2 & 0.891 & 0.632 & Valid \\
\hline 3 & 0.884 & 0.632 & Valid \\
\hline 4 & 0.908 & 0.632 & Valid \\
\hline 5 & 0.857 & 0.632 & Valid \\
\hline
\end{tabular}

Selanjutnya jika harga $r_{x y}$ dari masing-masing item di atas harga $r_{\text {tabel, maka keputusan }}$ pengujian validitas tes yang mencerminkan kemampuan berpikir kreatif dinyatakan valid.

\section{b. Realibilitas Soal}

Untuk mencari koefisien realibilitas instrumen tes uraian adalah dengan menggunakan formula (rumus) Alpha yang perhitungannya tidak dilakukan secara manual melainkan dengan bantuan program statistik yaitu SPPS 17.0. Berikut hasil perhitungan realibilitas tes bentuk uraian yang terdiri dari 5 butir (item):

Reliability Statistics

\begin{tabular}{|l|l|}
\hline $\begin{array}{l}\text { Cronbach's } \\
\text { Alpha }\end{array}$ & N of Items \\
\hline 0.891 & 5 \\
\hline
\end{tabular}

Dengan menggunakan kriteria realibilitas instrumen yang diadaptasi dari Sutrisno Hadi (dalam Ratnawulan dan Rusdiana, 2014: 175), maka alat penilaian yang memiliki koefisien realibilitas $r_{11}=0.814$ dikategorikan memiliki derajat realibilitas tinggi.

\section{c. Sensitivitas Butir Soal}

Setelah validitas dan realibilitas tes diketahui maka dilanjutkan dengan indeks sensitivitas butir soal. Berdasarkan hasil ujicoba terbatas, maka indeks indeks sensitivitas butir soal untuk membedakan antara peserta didik yang telah dan yang belum mengikuti kegiatan belajar mengajar sebagai berikut:

\begin{tabular}{|c|c|c|c|c|c|}
\hline No & Banyal & Subjek & \multirow{2}{*}{\multicolumn{2}{|c|}{ Proporsi }} & \multirow{3}{*}{$\mathrm{D}$} \\
\hline \multirow{2}{*}{$\begin{array}{l}\text { Buti } \\
\text { r }\end{array}$} & \multicolumn{2}{|c|}{ yang benar } & & & \\
\hline & $\begin{array}{l}\text { Postte } \\
\text { st }\end{array}$ & $\begin{array}{l}\text { Pretes } \\
\mathrm{t}\end{array}$ & $\begin{array}{l}\text { Postte } \\
\text { st }\end{array}$ & $\begin{array}{l}\text { Pretes } \\
\mathrm{t}\end{array}$ & \\
\hline 1 & 10 & 9 & 1 & 0.9 & 0.1 \\
\hline 2 & 10 & 9 & 1 & 0.9 & 0.1 \\
\hline 3 & 9 & 3 & 0.9 & 0.3 & 0.6 \\
\hline 4 & 8 & 4 & 0.8 & 0.4 & 0.4 \\
\hline 5 & 10 & 6 & 1 & 0.6 & 0.4 \\
\hline
\end{tabular}

Dengan perhitungan indeks sensitivitas butir soal diatas menunjukkan bahwa perolehan sensitivitas butir soal berada pada rentangan 0.1-0.6 berada dalam katagori cukup baik. 


\section{Implementasi Perangkat Pembelajaran pada Uji Coba II}

Setelah secara teoritis dan uji lapangan terbatas dinyatakan valid, realibel, memberikan efek postif dan terdapat perbedaan dalam pembelajaran. Selanjutnya, dalam implementasi perangkat pembelajaran pada uji coba II dilakukan untuk mengetahui konsistensi model problem based learning dengan bantuan metode mind mapping dalam kelas yang lebih luas yaitu pada kelas eksperimen dan kontrol.

\section{a. Analisis Data Kelas}

Setelah data terkumpul diperlukan adanya analisa data. Sebelum dianalisis diadakan uji persyaratan untuk mengetahui apakah data tersebut dapat digunakan sebagai dasar estimasi yang tidak bias dengan menggunakan analisis t-test. Adapun persyaratan tersebut adalah:

\section{1) Uji Normalitas}

Untuk pengujian normalitas data digunakan uji statistik normalitas Kolmogorov Smirnov dengan bantuan software SPSS 17.0. Berikut hasil pengujian normalitas data pretest dari dua kelas $\mathrm{V}$ di sekolah yang berbeda

\section{One-Sample Kolmogorov-Smirnov Test}

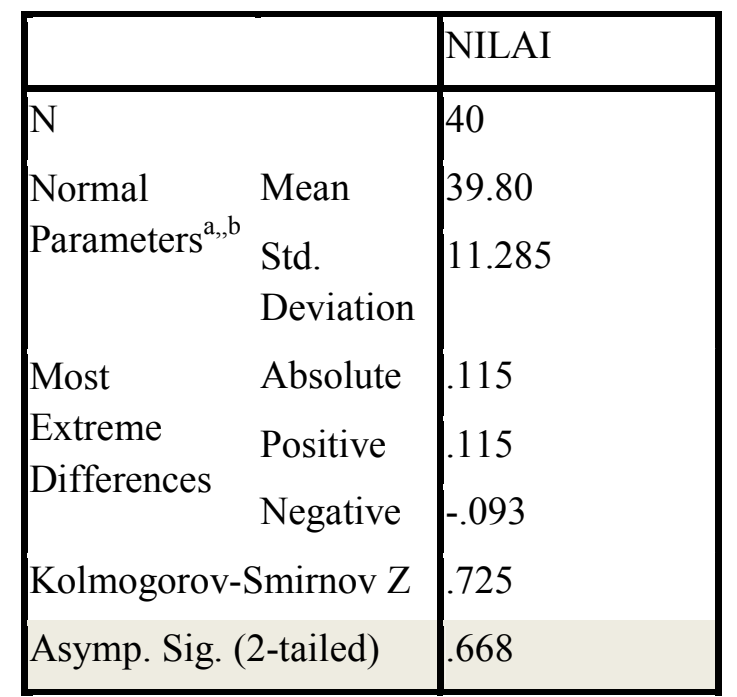

a. Test distribution is Normal.

b. Calculated from data.

Berdasarkan data yang diperoleh dari perhitungan hasil uji Kolmogorof-Smirnov (dapat disimpulkan bahwa data rata-rata berdistribusi normal karena memiliki Asymp.Sign $>0,05$. Hasil pretest dari dua kelas tersebut memliki sign 0.668 lebih besar dari nilai alpha (0.05). Sehingga dapat disimpulkan bahwa data berdistribusi normal.

\section{2) Uji Homogenitas}

Setelah kedua sampel penelitian tersebut dinyatakan berdistribusi normal, selanjutnya dicari nilai homogenitas dengan menggunakan bantuan Uji Homogenity of Variance test pada One-way Anova melalui SPSS 17.0, jika nilai signifikan $>0,05$ maka data terbukti homogen.

\section{Test of Homogeneity of Variances}

NILAI

\begin{tabular}{|l|l|l|l|}
\hline $\begin{array}{l}\text { Levene } \\
\text { Statistic }\end{array}$ & df1 & df2 & Sig. \\
\hline .000 & 1 & 38 & 1.000 \\
\hline
\end{tabular}

Berdasarkan hasil perhitungan data diatas, hasil pretest dari dua kelas tersebut memliki sign 1.000 lebih besar dari nilai alpha (0.05). Sehingga dapat disimpulkan bahwa data terbukti homogen.

\section{b. Analisis Data Kemampuan Berpikir Kreatif}

Setelah data terkumpul (hasil posttest kelas eksperimen dan kelas kontrol) diperlukan adanya analisa data. Sebelum dianalisis diadakan uji persyaratan untuk mengetahui apakah data tersebut dapat digunakan sebagai dasar estimasi yang tidak bias dengan menggunakan analisis t-test. sehingga diharapkan adanya perbedaan yang signifikan antara kelas eksperiman dan kelas kontrol. Adapun persyaratan tersebut adalah: 


\section{1) Uji Normalitas}

Untuk pengujian normalitas data digunakan uji statistik normalitas Kolmogorov Smirnov dengan bantuan software SPSS 17.0. Berikut hasil pengujian normalitas data kelas eksperimen dan kelas kontrol:

\section{One-Sample Kolmogorov-Smirnov Test}

\begin{tabular}{|c|c|}
\hline & NILAI \\
\hline $\mathrm{N}$ & 40 \\
\hline Normal Mean & 74.45 \\
\hline $\begin{array}{ll}\text { Paramete } & \text { Std. } \\
\mathrm{rs}^{\mathrm{a}, \mathrm{b}} & \text { Deviatio } \\
& \mathrm{n}\end{array}$ & 12.385 \\
\hline Most $\quad$ Absolute & .168 \\
\hline $\begin{array}{ll}\text { Extreme } & \text { Positive } \\
\text { Differenc } & \\
\text { es } & \text { Negative }\end{array}$ & $\begin{array}{l}.077 \\
-.168\end{array}$ \\
\hline $\begin{array}{l}\text { Kolmogorov- } \\
\text { Smirnov Z }\end{array}$ & 1.065 \\
\hline $\begin{array}{l}\text { Asymp. Sig. } \quad \text { (2- } \\
\text { tailed) }\end{array}$ & .273 \\
\hline
\end{tabular}

a. Test distribution is Normal.

b. Calculated from data.

Berdasarkan data yang diperoleh dari perhitungan hasil uji Kolmogorof-Smirnov (dapat disimpulkan bahwa data rata-rata berdistribusi normal karena memiliki Asymp.Sign $>0,05$. Hasil posttest dari kelas eksperimen dan kelas kontrol tersebut memliki sign 0.273 lebih besar dari nilai alpha (0.05). Sehingga dapat disimpulkan bahwa data berdistribusi normal.

\section{2) Uji Homogenitas}

Setelah kedua sampel penelitian tersebut dinyatakan berdistribusi normal, selanjutnya dicari nilai homogenitas dengan menggunakan bantuan Uji Homogenity of Variance test pada One-way Anova melalui SPSS 17.0, jika nilai signifikan $>0,05$ maka data terbukti homogen.
Test of Homogeneity of Variances

NILAI

\begin{tabular}{|l|l|l|l|}
\hline $\begin{array}{l}\text { Levene } \\
\text { Statistic }\end{array}$ & df1 & df2 & Sig. \\
\hline 5.929 & 1 & 38 & .020 \\
\hline
\end{tabular}

Berdasarkan hasil perhitungan data diatas, hasil pretest dari dua kelas tersebut memliki sign 0.020 lebih besar dari nilai alpha (0.05). Sehingga dapat disimpulkan bahwa data terbukti homogen.

\section{3) Pengujian Hipotesis}

Untuk membuktikan ada tidaknya perbedaan kemampuan berpikir kreatif dalam pembelajaran dengan menggunakan model problem based learning dengan bantuan metode mind mapping, maka digunakan uji $T$ test. Hasil uji $T$ test dapat diketahui, Jika nilai Sig.(2-tailed) $<0,05$ maka hipotesis terbukti artinya Ho ditolak dan Ha diterima.

Independent Samples

\begin{tabular}{|l|l|l|l|l|l|l|}
\hline \multicolumn{2}{|c|}{} & \multicolumn{3}{|l|}{ t-test for Equality of Means } \\
\cline { 2 - 7 } & T & Df & $\begin{array}{l}\text { Sig } \\
(2 . \\
\text { tailed })\end{array}$ & $\begin{array}{l}\text { Mean } \\
\text { Differe } \\
\text { nce }\end{array}$ & $\begin{array}{l}\text { Std } \\
\text { Error } \\
\text { Differen } \\
\text { ce }\end{array}$ \\
\hline Nilai & $\begin{array}{l}\text { Equal } \\
\text { Varie } \\
\text { nces } \\
\text { assum } \\
\text { ed }\end{array}$ & 8.816 & 38 & .000 & 20.350 & 2.308 \\
\hline
\end{tabular}

Berdasarkan hasil analisis dan aturan uji t, diperoleh signifikansi 0.000 lebih kecil daripada alpha 0.05, maka hipotesis "terdapat perbedaan kemampuan berpikir kreatif". 


\section{PENUTUP}

\section{Simpulan}

Berdasarkan rumusan masalah, hasil penelitian dan pembahasan maka dapat ditarik kesimpulan sebagai berikut:

(1) Produk perangkat pembelajaran hasil pengembangan dalam penelitian ini berupa RPP, LKS, Tes Kemampuan Berpikir Kreatif telah melalui proses validasi oleh ahli dengan kriteria valid. Hasil Validasi RPP diperoleh skror rata-rata keseluruhan adalah 3 termasuk katagori valid dengan penafsiran kevalidan sebesar $80 \%$. Hasil validasi LKS diperoleh skor rata-rata adalah 3.3 termasuk katagori valid dengan penafsiran kevalidan 83\%. Selanjutnya, Hasil telaah butir soal tes kemampuan berpikir kreatif diperoleh skr rata-rata 3.7 termasuk kategori valid dengan penafsiran kevalidan $91 \%$.

(2) Kepraktisan produk perangkat pembelajaran telah tercapai melalui analisis keterlaksanaan RPP yang sesuai dengan hasil pengamatan yang dilakukan oleh dua pengamat terhadap keterlaksanaan RPP dari pembelajaran problem based learning dengan bantuan metode mind mapping diperoleh skor rata-rata adalah 3.95 termasuk kategori sangat baik serta semua kegiatan yang tercantum dalam langkahlangkah kegiatan pembelajaran telah dilaksanakan dengan ketercapaian 97,5\%.

(3) Produk perangkat pembelajaran telah memenuhi kriteria keefektifan ditinjau dari aktivitas dan respon siswa. Frekuensi aktivitas siswa selama proses pembelajaran dikatagorikan baik dengan ketercapaian $80.42 \%$ dan $85 \%$. Selanjutnya, hasil analisis respon siswa terhadap pembelajaran menunjukkan $100 \%$ dari kategori respon favorable dan $92 \%$ dari kategori respon unfavorable.

(4) Berdasarkan hasil analisis dan aturan uji t, diperoleh signifikansi 0.000 lebih kecil daripada alpha 0.05, maka hipotesis "terdapat perbedaan kemampuan berpikir kreatif" antara kelompok eksperimen yang belajar menggunakan model pembelajaran problem based learning dengan bantuan metode mind mapping dengan siswa yang diajar menggunakan model pembelajaran konvensional.

\section{Saran}

1. Guru perlu melatih siswa untuk lebih mengembangkan kemampuan yang diperlukan pada pembelajaran yang menggunakan kurikulum 2013, yaitu penggunaan keterampilan yang dapat meningkatkan kemampuan berpikir kreatif siswa salah satunya dengan model pembelajaran problem based learning dengan bantuan metode mind mapping.

2. Pengembangan perangkat pembelajaran model problem based learning dengan bantuan metode mind mapping dapat meningkatkan keterampilan berpikir kreatif siswa SD kelas $\mathrm{V}$ pada materi peranan manusia tema 6 sehingga guru diharapkan dapat melanjutkan pengembangan perangkat pembelajaran dengan model tersebut terhadap materi yang lain sehingga lebih memudahkan siswa dalam memunculkan kreativitasnya.

3. Guru kelas diharapkan agar selalu terbiasa menggunakan model-model pembelajaran yang sifatnya membangun ide dan kreativitas siswa dengan harapan proses proses kegiatan belajar mengajar dapat berjalan dengan efektif, aktif, dan tidak menjemuka.

\section{DAFTAR PUSTAKA}

Adams, Ken. (2006). Semua Anak Jenius. Jakarta: PT Gelora Aksara Pratama.

Akbar, Sa'dun. (2013). Instrument Perangkat Pembelajaran. Bandung: PT Remaja Rosdakarya. 
Amir, Taufik. M. (2013). Inovasi Pendidikan Melalui Problem Based Learning. Jakarta: Kencana Prenada Media Group.

Arikunto, Suharsimi. (2010). Prosedur Penelitian Suatu Pendekatan Praktik. Jakarta: PT Rineka Cipta.

Arikunto, Suharsimi. (2012). Dasar-Dasar Evaluasi Pendidikan. Jakarta: PT Bumi Aksara.

Buzan, Tony. (2005). Mind Map. Jakarta: PT Gramedia Pustaka.

Buzan, Tony. (2008). Mind Map untuk Meningkatkan Kreativitas. Jakarta: PT Gramedia Pustaka.

Kosasih, E. (2014). Strategi Belajar dan Pembelajaran Implementasi Kurikulum 2013. Bandung: Yrama Widya.

Munandar, Utami. (2012). Pengembangan Kreativitas Anak Berbakat. Jakarta: Rhineka Cipta.

Nasution. (2011). Kajian Pembelajaran IPS di Sekolah. Surabaya: Unesa University Press.

Nur, Mohamad. (2011). Model Pembelajaran Berdasarkan Masalah. Surabaya: Pusat Sains dan Matematika Sekolah UNESA.

Peterson, Anne. R, Snyder, Paula J. (1998). Using Mind Map to Teach Social Problem Analysis. Paper Presented at the Annual Meeting of the Society for the Study of Social Problems $\left(48^{\text {th }}\right.$, San Francisco, CA, August 20-22, 1998)
Ratumanan, Gerson Tanwey dan Laurens Theresia. (2011). Penilaian Hasil Belajar pada Tingkat Satuan Pendidikan Edisi 2. Surabaya. Unesa University Press.

Ratnawulan dan Rusdiana. (2014). Evaluasi Pembelajaran. Bandung: CV Pustaka Setia.

Riyanto, Yatim. (2012). Paradigma Baru Pembelajaran. Jakarta: Kencana Prenada Media Group.

Rusman. (2012). Model-Model Pembelajaran. Jakarta: Rajawali Pers.

Sapriya. (2009). Pendidikan IPS. Bandung: PT Remaja Rosdakarya.

Sudjana, Nana. (2012). Penilaian Hasil Proses Belajar Mengajar. Bandung: PT Remaja Rosdakarya.

Sugiyono. (2011). Metode Penelitian Kuantitatif Kualitatif dan R\&D. Bandung: Alfabeta.

Sugiyono. (2012). Statistika untuk Penelitian. Bandung: Alfabeta.

Sumardi Lalu. (2012). Revitalisasi Pembelajaran IPS SD Sebagai Upaya Menciptakan Peserta Didik yang Berkarakter. Vol 11 No 2 September 2012, $157-164$.

Suryanti, dkk. (2008). Model-model Pembelajaran Inovatif. Surabaya: UNESA University Press.

Susanto, Ahmad. (2014). Pengembanagan Pembeljaran IPS di Sekolah Dasar. Jakarta: Prenada Media Group. 
Semiawan, Conny R, dkk. (2009). Kreativitas Keberbakatan. Jakarta: PT Indeks.

Tilaar, H. A.R. (2012). Pengembangan Kreativitas dan Entrepreneurship. Jakarta: PT Kompas Media Nusantara.

Thiagarajan, S., Semmel, D. S., \& Semmel, M. I. (1974). Instructional development for training teachers of exceptional children: a sourcebook. Washington, DC: Indiana University.

Trianto. (2007). Model-model Pembelajaran Inovatif Berorientasi Kontruktivistik. Jakarta: Prestasi Pustaka Publisher.

Trianto. (2010). Model Pembelajaran Terpadu. Jakarta: PT Bumi Aksara.

Wallden, Sari, and Makinen, Erkki. (2013). Educational Data Mining and Problem Based Learning. University of Tampere, School of Information Sciences.

Walsh, Vonda. K, and Bush, H. Francis. (2013). An Evaluation of a Problem Based Learning. Virginia Military Institute. USA (Contemporary Issues in Education Research- Fourth Quarter 2013 Volume 6, Number 4).

Winataputra, Udin S., dkk. (2011). Materi dan Pembelajaran IPS SD. Jakarta: Universitas Terbuka.

Wheeldon, Johannes. (2011). Using Mind Maps to facilitate Participant Recall in Qualitative Research (Volume 16 Number 2 March 2011 509-522) Simon Fraser University: Canada.
Yamin, Martinis. (2013). Strategi dan Metode dalam Model Pembelajaran. Jakarta: GP Press Group. 